\title{
A Brief Historical Perspective on Dental Implants, Their Surface Coatings and Treatments
}

\author{
Celeste M. Abraham*
}

Texas A and M University Health Science Center, Baylor College of Dentistry, Department of Periodontics, 3302 Gaston Avenue, Room 142, Dallas, Texas, 75246

\begin{abstract}
This review highlights a brief, chronological sequence of the history of dental implants. This historical perspective begins with ancient civilizations and spotlights predominant dentists and their contributions to implant development through time. The physical, chemical and biologic properties of various dental implant surfaces and coatings are discussed, and specific surface treatments include an overview of machined implants, etched implants, and sand-blasted implants. Dental implant coatings such as hydroxyapatite, fluoride, and statin usage are further reviewed.
\end{abstract}

Keywords: Dental history, implant surface, implants, surface coating.

\section{A BRIEF HISTORY OF DENTAL IMPLANTS}

\author{
"There's Gold (Ivory and Stone) in them thar (Im- \\ plants)"'!
}

The history of the evolution of dental implants is a rich and fascinating travelogue through time. Since the beginning of mankind, humans have used dental implants in one form or another to replace missing teeth. In approximately $2500 \mathrm{BC}$, the ancient Egyptians tried to stabilize teeth that were periodontally involved with the use of ligature wire made of gold. Their manuscripts and texts allude to several interesting references to toothaches. About $500 \mathrm{BC}$, the Etruscans customized soldered gold bands from animals to restore oral function in humans; they also fashioned replacements for teeth from oxen bones. At about the same period, the Phoenicians used gold wire to stabilize teeth that were periodontally involved; around $300 \mathrm{AD}$, these innovative peoples used teeth creatively carved out of ivory which were then stabilized by gold wire to create a fixed bridge. The first evidence of dental implants is attributed to the Mayan population roughly around 600 AD where they excelled in utilizing pieces of shells as implants as a replacement for mandibular teeth. Radiographs taken in the 1970's of Mayan mandibles show compact bone formation around the implants-bone that amazingly looks very much like that seen around blade implants! Moreover, around 800 AD, a stone implant was first prepared and placed in the mandible in the early Honduran culture [1].

\section{From Rocks to Roosters- Early Implants Emerge}

In the middle of the 1600's periodontally compromised teeth were stabilized in Europe with various substances.

*Address correspondence to this author at the Texas A and M University Health Science Center, Baylor College of Dentistry, Department of Periodontics, 3302 Gaston Avenue, Room 142, Dallas, Texas, 75246;

Tel: 214-828-8467; Fax: 214-874-4563; E-mail: cabraham@bcd.tamhsc.edu
From the 1500's to about the 1800's, teeth in Europe were collected from the underprivileged or from cadavers for the use of allotransplantation. During this period, Dr. John Hunter came on to the scene; for many years he worked with "resurrectionists"-people who acquired corpses underhandedly through the robbing of graves. By doing so, he was able to observe and document with great detail the anatomy of the mouth and jaw. In the 1700's, Dr. Hunter suggested transplanting teeth from one human to another; his experiment involved the implantation of an incompletely developed tooth into the comb of a rooster. He observed an extraordinary and astonishing event: the tooth became firmly embedded in the comb of the rooster and the blood vessels of the rooster grew straight into the pulp of the tooth $[1,2]$. In 1809, J. Maggiolo inserted a gold implant tube into a fresh extraction site. This site was allowed to heal and then a crown was later added; unfortunately, there was extensive inflammation of the gingiva which followed the procedure $[1,3]$. Innumerable substances during this time period were used as implants; these included silver capsules, corrugated porcelain, and iridium tubes $[1,3]$.

\section{Brothers Strock to Building Spirals}

Dr. EJ Greenfield, in 1913, placed a "24-gauge hollow latticed cylinder of iridio-platinum soldered with 24-karat gold" as an artificial root to "fit exactly the circular incision made for it in the jaw-bone of the patient "[4]. In the 1930's, two brothers, Drs. Alvin and Moses Strock, experimented with orthopedic screw fixtures made of Vitallium (chromium-cobalt alloy). They carefully observed how physicians successfully placed implants in the hip bone, so they implanted them in both humans and dogs to restore individual teeth. The Vitallium screw provided anchorage and support for replacement of the missing tooth. These brothers were acknowledged for their work in selecting a biocompatible metal to be used in the human dentition [5]. The Strock brothers were also thought to be the first to place the first 
successful endosteal (in the bone) implant. (Incidentally, Dr. Alvin Strock not only worked with implant materials, he also established the use of antibiotics for shipboard treatment of periodontal infections like trench mouth). In 1938, Dr. P.B. Adams patented a cylindrical endosseous implant that was threaded both internally and externally; it had a smooth gingival collar and a healing cap [6]. A post-type endosseous implant was developed by Formiggini ("Father of Modern Implantology") and Zepponi in the 1940's. The spiral stainless steel design of the implant allowed bone to grow into the metal [5]. This spiral implant was made by constructing a stainless steel wire on itself. Dr. Perron Andres from Spain modified Formiggini's spiral design to include a solid shaft in the construction [5].

\section{Implant Discovery Continues... The Fabulous Forties and Fantastic Fifties}

Dr. Raphael Chercheve from France added to the spiral design by creating burs to ease the insertion of the implant for a best fit. As the progression of implant discovery continued, the subperiosteal (on the bone) implant was developed in the 1940's by Dahl in Sweden. 5 Dahl's original implant design involved flat abutments and screws which lay over the crest of the alveolar ridge. Dahl's work was carried on by Gershkoff and Goldberg as well as Weinberg in the United States from 1947-1948 [5]. Gershkoff and Goldberg produced a cobalt-chromium-molybdenum implant with an extension of Dahl's design to include the external oblique ridge [7]. The subperiosteal implant design was further researched and elaborated upon by Lew, Bausch, and Berman in 1950 [5]. Lew utilized a direct impression method which used fewer supports over the ridge crest [5]. In the 1950's, Dr. Bodine observed several patients in the armed forces; the framework design seemed to be more streamlined now and he found that fewer struts or girders were needed. The holes for the screws were located in areas where the bone had the greatest strength and thickness [8]. This decade also included the innovations of Dr. Lee who introduced the use of an endosseous implant with a central post [5].

\section{Increase of Implant Innovation: 1960's-1970's}

Various implant designs expanded in the 1960's. Dr. Cherchieve crafted a double-helical spiral implant; it was made of cobalt and chromium [9]. Many of these were screw-shaped and in a single piece. The spiral shaft was further enhanced during this decade by Dr. Giordano Muratori by the addition of internal threading to the shaft of the implant [5]. The basic spiral design was turned into a flat plate with various configurations by Dr. Leonard Linkow in 1963 $[10,11]$. In 1967, there were two variations of the blade implant that were introduced by Linkow, making it possible to place it in either the maxilla or the mandible. Linkow developed the Ventplant implant $[10,11]$. The blade implant is now recognized as an endosseous implant. Further on, Dr. Sandhaus in the mid-60's developed a crystallized bone screw whose composition was mainly that of aluminum [12].

As the 1960's came to a close and the 1970's began, doctors Roberts and Roberts began the development of the Ramus Blade endosseous implant. This implant was made of surgical grade stainless steel; according to them, it was to serve as a "synthetic third molar" [5]. They also developed the ramus frame implant which received its stability by anchoring in the ramus bilaterally as well as in the symphysis area. The 1970's brought in the placement of vitreous carbon implants by Grenoble [13]. Weiss and Judy made popular the use of intramucosal inserts during this time; the inserts helped in the retention of removable maxillary prostheses [14]. In 1975, an implant device placed through a submental incision and attached to the mandible was introduced by Dr. Small; this was known as the first transosteal implant called the mandibular staple implant. This would help those individuals who had an edentulous mandible that was atrophic in nature [15].

\section{Splendid Serendipity}

In 1978, Dr. P. Brånemark presented a two-stage threaded titanium root-form implant; he developed and tested a system using pure titanium screws which he termed fixtures [16]. These were first placed in his patients in 1965 and were the first to be well-documented and the most wellmaintained dental implants thus far. Brånemark's first patient had severe deformities of the jaw and chin, congenitally missing teeth and misaligned teeth. Four implants were inserted into the mandible. These implants integrated within a period of six months and remained in place for the next 40 years [17]. He found this discovery accidentally in 1952 when he was studying blood flow in rabbit femurs by placing titanium chambers in their bone; over time the chamber became firmly affixed to the bone and could not be removed [18]. The bone actually bonded to the titanium surface. In fact if a fracture occurred, it always occurred between bone and bone, never between the bone and the implant. He carried over this idea into the realm of dentistry. With his implant came the concept of "osseointegration" and the confidence that dental implant education could be introduced into dental school curricula. This term was further refined and defined by Brånemark as "a direct structural and functional connection between ordered, living bone, and the surface of a load carrying implant" [19]. The original Brånemark implant was created as a cylindrical one; later on tapered forms appeared. Many other types of implants were introduced after the Brånemark implant which included the ITI-sprayed implant, the Stryker implant, the IMZ implant and the CoreVent implant [20].

\section{Trailblazing and Trendsetting Titanium}

Two other ground-breaking persons of modern implantology were Dr. Schroder and Dr. Straumann of Switzerland. They experimented with metals utilized in orthopedic surgery to help fabricate dental implants [21]. Beginning in the middle of the 1980's, the customary implant used by many dental clinicians was the endosseous root-form implant. The major factors that determined which endosseous implant system was chosen over another included the design, the surface roughness, prosthetic considerations, ease of insertion into the bone, costs and how successful they were over a period of time. Dr. Tatum introduced the omni R implant in the early 1980's; it had horizontal fins made up of titanium alloy [22]. Dr. Niznick introduced the Core-Vent implant in the early part of the 1980's. It was a hollow basket implant 
with a threaded piece in it which helped to engage the bone; he also manufactured the Screw-Vent implant which had a hydroxyapatite coating on it. This surface coating was to allow for more immediate adaptation of the bone to the implant surface. The Core-Vent company also designed the Swede-Vent implant which used an external hexagonal interface to hold the abutment. Dr. Niznick continued to develop other systems including the Bio-Vent and the Micro-Vent. [23].

Soon after, Dr. Driskell in the 1980's introduced the Stryker "root form" endosseous implant; there are two versions of this-one made with a titanium alloy and another coated with hydroxylapatite [24]. The IMZ implant which was introduced by Dr. Kirsch towards the end of the 1970's, was widely used in many countries in the 1980's [25]. The IMZ implant had some distinctive features; it had a titanium surface spray to increase interface surface area and it also had an intra-mobile element in it to duplicate the mobility of natural teeth. The Calcitek Corporation in the early 1980's started making a synthetic polycrystalline ceramic hydroxylapatite called calcitite. In 1985 it produced the Integral Implant System [26]. The ITI implant system introduced in 1985 by the Straumann Company has exclusive plasmasprayed cylinders and screws which are designed to be placed in a one-stage operation. [27] The most recent dental implant innovations involve the use fluoride' antibiotics, growth factors and laminan.

\section{Dental Implant Surfaces and Coatings: An Overview}

One of the main reasons for the modification of dental implant surfaces is to decrease the healing time for osseointegration. The surface of a dental implant is the only part that is in contact with the bio-environment and the uniqueness of the surface directs the response and affects the mechanical strength of the implant/tissue interface [28-31]. Several diverse surface texturing of titanium implant substrates have been tested to improve osseointegration. The surface treatment layer on the implant is required to increase the functional surface area of the implant-bone interface so that stress is effectively transferred. Additionally, the surface coating promotes bone apposition [32]. This may include mechanical treatments (machining and grit blasting for instance), chemical treatments (acid etching for example), electrochemical treatments (anodic oxidation), vacuum treatments, thermal treatments, and laser treatments [33].

These surface treatments were found to control the growth and metabolic action of cultured osteoblasts. Surface roughness has also been shown to influence cytokine and growth factor production by osteoblasts; increased surface roughness allowed transforming growth factor-beta (TGF- $\beta$ ) production which directly increased osteoblast cell propagation [34]. The surface roughness of an implant has an irrefutable effect on cell movement as well as cell growth. This suggests that the structure of the implant influences the interaction between the metal and the living tissue $[35,36]$.

\section{The Manufacturing of Machined Implants}

The original osseointegrated implants had a moderately smooth machined surface [37]. They are called machined or turned implants. After being manufactured, these implants are cleaned, decontaminated and sterilized. Microscopic examination shows the machined implant surfaces contain surface markings of the instruments that are employed for their development. Surface imperfections are a manner in which the bone can interlock with the metal. The disadvantage of the shape of machined implants is that bone-forming cells tend to proliferate along surface grooves. This requires a longer time but keeps to $\mathrm{a}$ method elaborated by Brånemark which involves a healing time of three to six months before loading. These implants show good long-standing outcomes in the clinical arena when they are used in areas with adequate bone allowing for a two-stage process [37].

An etched surface dental implant is another classification of surface treatments. Etching with strong acids like a mixture of hydrochloric acid and sulfuric acid is an alternative way to roughen implants made of titanium. The process of titanium etching allows for the eradication of the oxide layer as well as portions of the underlying material of the implant [38]. The process of treatment with an acid provides for equal roughness, an active surface area and better adhesion [39]. The etched acid surface makes possible the preservation of bone-forming cells and provides a mechanism for them to make their way onto the surface of the implant. This allows for improved viability and cellular adherence. The acid-etched surface roughens the implant surface and produces tiny spots on the surface of the titanium. Acid etching has been shown to improve osseointegration for many years $[40,41]$. Additionally there is a technique where titanium implants where the titanium implants are soaked in a blend of concentrated hydrochloric acid and sulfuric acid. This method allows fibrin and osteogenic cells to attach which results in the formation of bone on top of the implant [42].

\section{Hydroxyapatite Coating and Titanium Plasma Sprayed Coatings}

Hydroxyapatite (HA) is a material that has the potential to form a strong bond between the bone and the implant, may form a direct and strong binding between the implant and bone tissue. Hydroxyapatite coating is a layering of calcium and phosphate on the implant [43]. Hydroxyapatite has been applied onto metals in various ways. Plasma spraying allows the implant to have a coating thickness of approximately 40-50 micrometers. This process involves the injection of powdery forms of titanium into a plasma torch at elevated temperatures. These particles subsequently condense and fuse together on the implant surface. Phosphated titanium increased TGF- $\beta 1$ production at 8 days and induced nodule mineralization even in the absence of mineralizing medium [44]. Nano-hydroxyapatite-coated surfaces in the transmucosal region have recently been studied and have been thought to be as compatible as pure titanium surfaces [45]. A major concern noted in cases of plasma sprayed coatings is that the hydroxyapatite may undergo resorption and further degradation and ultimately cause loosening of the titanium particles. The plasma-spraying method has several drawbacks, including poor long-term adherence of the coating to the substrate material, uneven thickness of the deposited layer, and dissimilarities in composition of the coating. Other significant factors causing implant failures include microbial infections [46, 47]. Other coating surfaces include composite coatings, titanium nitride coatings, carbon, glass, 
and ceramic coatings as well as titanium dioxide film coatings [32].

\section{Sand-blasted and Etched Implants: A Particular Process}

Sandblasted (large grit) and acid-etched (SLA) implants are formed by an extensive process of blasting which in turn is followed by etching with both sulfuric acid and hydrochloric acid. It results in surface roughness and has an excellent bone integration [48]. Titanium or alumina particles complete the grit blasting technique. Changing the size of the particle can affect the final surface roughness. Alumina and titanium particles with sizes of 25 micrometers and $75 \mathrm{mi}$ crometers on titanium implants made for better formation of bone as compared to implants that were machined [49-51].

\section{A Chemical Course of Treatment}

An electrochemical process that allows the titanium oxide layer to increase as well as become rough is known as anodic oxidation. This process allows for increased biocompatibility. What finally comes about is a surface which manifests tiny pores that show increased cell adhesion and transmission. Machined implants have a slower healing time as compared to anodized implants. In a study performed on dog models, greater bone density was noted around anodized implants than their machined counterparts [52]. Anodization was used to generate niobium oxide coatings on sand-blasted titanium alloy dental implants; these oxide coatings were found to advance osseointegration [53].

\section{A Flexible Function of Fluoride}

Fluoride treatment can also be applied to the surface of implants. It provides for superimposition of nanofeatures onto micro-roughened surfaces. Titanium combines with fluoride to form soluble $\mathrm{TiF}_{4}$ allowing for enhanced osseointegration and differentiation of osteoblasts [54]. Implants which were fluoridates and roughened, had higher removal torque than the control implants [55].

\section{Resilience and Strength: Lasers and Ions}

Surface preparation by laser ablation of dental implants is another method to enhance bone-to-metal interfaces. Very hard titanium microstructure surfaces, great resistance to weakening, an excellent roughness as well as increased oxide layer are a result of this procedure $[56,57]$. Biological studies have demonstrated grooved surfaces which prepare the way for cell attachment and direct the manner in which they grow [58].

Another process is called sputtering. This occurs when molecules of a material are emitted in a vacuum chamber by the attack of ions of high energy. A disadvantage of this process is that it takes a long time for deposition to occur [59].

\section{Medication Muscle: Bisphosphonates and Stains}

Improved osseointegration has been seen with implant surfaces loaded with bisphosphonates [60, 61]. They are antiresorptive and prevent bone loss as well as increase the mass of bone for patients [62-64]. The effect of the bisphos- phonate only takes place at the area of the implant. In vivo studies have revealed a small increase in osseointegration with these drugs. Experiments incorporating zoledronate and pamidronate showed an increase in bone contact area [65, 66].

Statins are prescribed medications used to decrease the liver synthesis of cholesterol [67]. With implants, Simvastatin, has been shown to enhance the expression of certain types of bone morphogenetic protein that might promote bone formation [68]. Researchers have found that applying statins to alveolar bone increased bone formation and suppressed osteoclastic activity. Statins have also been shown to increase the density of bone [69-71]. Simvastatin loaded implants showed increased action of osteoblasts [72].

\section{Antibiotic Abilities}

The placement of antibiotic coatings on implants has been researched as a possible way to disallow infection to get a hold of the surgical site. Hydroxyapatite along with gentamicin as well as antibiotics of a systemic nature can be coated on to the surface of the implant prior to the surgical placement of the implant [73]. It functions as an antibacterial agent; this antibiotic can also remove virulent endotoxins from the implant surface [74]. Tetracycline has been found to strongly support osseointegration.

\section{The Grandeur of Growth Factors}

Growth factors such as bone morphogenetic proteins (BMPs), platelet-derived growth factor (PDGF) and TGF- $\beta 1$ on titanium implant surfaces augment the healing of bone [75-78]. The role of the TGF- $\beta 1$ application to calciumphosphate implant surfaces has been studied in goats [79]. The disadvantage in the use of growth factors in treating the surfaces of implants is that the active growth factor has to be released over a period of time.

\section{State-of-the-art Ingenuity and Innovation}

Finally, progressive researchers at the Universitat Jaume I in Castelon have recently developed an implant coating with a novel biodegradable material to help people with bone deficits such as osteoporosis. It is called the Soldent project and consists of covering the implant with a biodegradable coating that, when it comes in contact with bone, dissolves and releases compounds containing silicon to allow bone to generate [80]. Another new implant coating is Laminin I. This may enhance osseointegration comparable to a bioactive implant surface while keeping the surface smooth [81].

\section{CONCLUSION}

In summary, the history of the development and advancement of dental implants is a magnificent and fascinating journey through time. One can only stop and marvel at man's ingenuity over the years in this arena of research and scholarship. The materials in which dental implants came into development range from gold ligature wire, shells, ivory to chromium, cobalt, to iridium and platinum. From spiral stainless steel implant designs to double helical creations and endosseous root forms, dental researchers and clinicians 
worked fast and furiously; they generated many structures to replace the positions that natural teeth once held. Dental surfaces were also modified to decrease the healing time for osseointegration. Modified surfaces incorporated the use of hydroxyapatite, composites, carbon, glass, ceramic as well as titanium oxide. In order to make the exterior as suitable as possible, implant surfaces have additionally been sandblasted, oxidized, fluoridated, etched, and medicated. The most recent innovative laminan coating is the center of focus in present day implant endeavors. As time marches on in dental implant study, the materials, forms, and surface coatings have been refined and restructured to allow the consumer the very best in tooth replacement choices for their present and future needs.

\section{CONFLICT OF INTEREST}

The author confirms that this article content has no conflict of interest.

\section{ACKNOWLEDGEMENTS}

Declared none.

\section{REFERENCES}

[1] Ring Malvin E. Dentistry: an illustrated history. $2^{\text {nd }}$ ed. Abradale Press 1985.

[2] Asbell, Milton B. Dentistry, a historical perspective: being a historical account of the history of dentistry from ancient times, with emphasis upon the United States from the colonial to the present period. Bryn Mawr, Pa: Dorrance \& Co, 1988; 1-256.

[3] Maggiolo: Manuel de l'art dentaire [Manuel of dental art], Nancy, France, 1809, C. Le Seure.

[4] Greenfield EJ. Implantation of artificial crown and bridge abutments. Int J Oral Implant 1991; 7(2): 63-8.

[5] Linkow LI, Dorfman JD. Implantology in dentistry: A brief historical perspective. N Y State Dent J 1991; 57(6): 31-5.

[6] Burch RH. Dr. Pinkney Adams-a dentist before his time. Ark Dent 1997; 68(3): 14-5.

[7] Goldberg NI, Gershkoff A. The implant lower denture. Dent Dig 1949; 55(11); 490-4.

[8] Bodine RL. Experimental subperiosteal dental implants. U.S. Armed Forces Med J 1953; 4: 441-51.

[9] Cherchieve R. Considerazioni fisiologiche e pratiche su una osservazione originale di un impianto endosseo, Inform Dent 1959; 24 : 677-80.

[10] Linkow LI. Intraosseous implants utilized as fixed bridge abutments. J Oral Implant Transplant Surg 1964; 10: 17-23.

[11] Linkow LI. The radiographic role in endosseous implants interventions. Chron Omaha District Dent Soc 1966; 29; 304-11.

[12] Sandhaus S. Tecnica e strumentario dell'impianto C.B.S. (Crystalline Bone Screw). Informatore Odonto-Stomatologico 1968; 4: 1924.

[13] Markle DH, Grenoble DE, Melrose RJ. Histologic evaluation of vitreous carbon endosteal implants in dogs. Biomater Med Dev Artif Organs 1975; 3(1): 97-114.

[14] Weiss CM, Judy KW. Intramucosal inserts solve patients' problems with maxillary dentures. II. Quintessence Int Dent Dig 1974; 5(4): $9-15$.

[15] Small IA, Misiek D. A sixteen-year evaluation of the mandibular staple bone plate. J Oral Maxillofac Surg 1986; 44: 60-6.

[16] Brånemark PI, Zarb G, Albrektsson T. Tissue-integrated prostheses: Osseointegration in clinical dentistry. Chicago: Quintessence Publishing 1985.

[17] Brånemark PI, Hansson BO, Adell R, et al. Osseointegrated implants in the treatment of the edentulous jaw: Experience from a 10-year period. Scand J Plast Reconstr Surg 1977; 16: 1-132.
[18] Brånemark PI. Osseointegration and its experimental background. J Prosthet Dent 1983; 50 (3): 399-410.

[19] Osteointegration: Associated Branemark Ossointegration Centers 2010. Available from:

http://www.branemark.com/Osseointegration.html

[20] SF1 Barg Implant Abutments: Sterngoid Dental, LLC 13 March, 2013 Available from:

http://www.accessdata.fda.gov/cdrh_docs/pdf13/K130183.pdf

[21] LeneyWR. In recognition of an implant pioneer: Prof. Dr. Andre Schroeder. Int J Oral Maxillofac Implants 1993; 8(2): 135-6.

[22] Tatum OH. The Omni implant system. In: Hardin J, Ed. Clarke's Clinical Dentistry. Vol 5. Philadelphia, Pa: JB Lippincott 1984.

[23] Dr. Gerald A. Niznick. Available from: http://www.implantdirect.com/us/ajaxtabs/about_us/tab_6.htm

[24] Driskell TD. The stryker precision implant system: Root form series, McKinney RV: Endosteal dental implants, Mosby Year Book 1991; 8.

[25] Kirsch A, Ackermann KL. The IMZ osseointegrated implant system. Dent Clin North Am 1989; 33(4): 733-91.

[26] Part 2: Internal Non-Hex Connection 2007 ; 292-303. Available from: http://www.swissnf.com/implant_procedures/integral.pdf

[27] Straumann USA LLC 2014. Available from: http://www.straumann.us/

[28] Eriksson C, Lausmaa J, Nygren H. Interactions between human whole blood and modified $\mathrm{TiO}_{2}$-surfaces: Influence of surface topography and oxide thickness on leukocyte adhesion and activation. Biomaterials 2001; 22: 1987-96.

[29] Wen X, Wang X, Zhang N. Microsurface of metallic biomaterials: A literature review. J BioMed Mater Eng 1996; 6: 173-89.

[30] Albrektsson T, Jacobsson M. Bone-metal interface in osseointegration. J Prosthet Dent 1987; 57: 5-10.

[31] Schroeder A, van der Zypen E, Stich H, Sutter F. The reactions of bone, connective tissue and epithelium to endosteal implants with titanium sprayed surfaces. J Maxillofac Surg 1981; 9: 15-25.

[32] Sabane AV. Surface characteristics of dental implants: A review. J Indian Acad Dental Special 2011; 2 (2): 18-21.

[33] Alla RK, Ginjupalli K, Upadhya N, Shammas M, Rama Krishna R, Ravichandra S. Surface roughness of implants: A review. Trends Biomat Artif Org 2011; 25(3): 112.

[34] Boyan BD, Lossdorfer S, Wang L, et al. Osteoblasts generate an osteogenic microenvironment when grown on surfaces with rough microtopographies. Eur Cell Mater 2003; 6: 22-7.

[35] Matsuo M, Nakamura T, Kishi Y, Takahashi K. Microvascular changes after placement of titanium implants: Scanning electron microscopy observations of machined and titanium plasma-sprayed implants in dogs. J Periodontol 1999; 70: 1330-8.

[36] Novaes AB Jr, Souza SL, de Oliveira PT \& Souza AM. Histomorphometric analysis of the bone-implant contact obtained with 4 different implant surface treatments placed side by side in the dog mandible. The Int J Oral Maxillofac Implants 2002; 17: 377-83.

[37] Brånemark PI, Zarb GA, Albrektsson T. Tissue Integrated Prostheses. Chicago: Quintessence 1985; 201-8.

[38] MacDonald D, Rapuano B, Deo N, Stranick M, Somasundaran P, Boskey A. Thermal and chemical modification of titaniumaluminum-vanadium implant materials: Effects on surface properties, glycoprotein adsorption, and MG63 cell attachment. Biomaterials 2004; 25: 3135-46.

[39] Braceras I, De Maeztu MA, Alava JI, Gay-Escoda C. In vivo lowdensity bone apposition on different implant surface materials. Int J Oral Maxillofac Implants 2009; 38; 274-8.

[40] Cho SA, Park KT. The removal torque of titanium screw inserted in rabbit tibia treated by dual acid etching. Biomaterials 2003; 24: 3611-7.

[41] Wong M, Eulenberger J, Schenk R, Hunziker E. Effect of surface topology on the osseointegration of implant materials in trabecular bone. J Biomed Mater Res 1995; 29: 1567-75.

[42] Park JY, Davies JE. Red blood cell and platelet interactions with titanium implant surfaces. Clin Oral Implant Res 2000; 12: 530-9.

[43] Ducheyne P, Cuckler JM. Bioactive ceramic prosthetic coatings. Clin Orthop Relat R 1992; 39(276): 102-14.

[44] Dacy JA, Spears R, Hallmon WW, et al. Effects of phosphated titanium and enamel matrix derivatives on osteoblast behavior in vitro. Int J Oral Maxillofac Implants 2007; 22(5): 701-9.

[45] De Wilde EA, Jimbo R, Wennerberg A, et al. The soft tissue immunologic response to hydroxyapatite-coated transmucosal implant surfaces: A study in humans. Clin Implant Dent Relat Res 2013. 
[46] Rosenberg ES, Torosian JP, Slots J. Microbial differences in two clinically distinct types of failures of osseointegrated implants. Clin Oral Implants Res 1991; 2: 135-44.

[47] Verheyen CC, Dhert WJ, Petit PL, Rozing PM, de Groot K. In vitro study on the integrity of a hydroxylapatite coating when challenged with staphylococci. J Biomed Mater Res 1993; 27: 775-81.

[48] Bornstein MM, Valderrama P, Jones AA, Wilson TG, Seibl R, Cochran DL. Bone apposition around two different sandblasted and acid-etched titanium implant surfaces: A histomorphometric study in canine mandibles. Clin Oral Implan Res 2008; 19: 233-41.

[49] Engquist B, Astrand P, Dahlgren S, Engquist E, Feldmann H, Grondahl K. Marginal bone reaction to oral implants: A prospective comparative study of Astra Tech and Brånemark System implants. Clin Oral Implan Res 2002; 13: 30-7.

[50] van Steenberghe D, De Mars G, Quirynen M, Jacobs R, Naert I. A prospective split-mouth comparative study of two screw-shaped self-tapping pure titanium implant systems. Clin Oral Implan Res 2000; 11: 202-9.

[51] Gupta A, Dhanraj M, Sivagami G. Status of surface treatment in endosseous implant: A literary overview. Ind J Dent Res 2010; 21: 433-8.

[52] Gurgel BC, Goncalves PF, Pimentel SP, et al. An oxidized implant surface may improve bone-to-implant contact in pristine bone and bone defects treated with guided bone regeneration: An experimental study in dogs. J Periodontol 2008; 79: 1225-31.

[53] Allen CM, Robert LK, Tien-Mien G, Chu Meoghan Mac P, Daniel LA. Development of niobium oxide coatings on sand-blasted titanium alloy dental implants. Mat Sci Applic 2012; 3(5): 301-5.

[54] Ellingsen J. Pre-treatment of titanium implants with fluoride improves their retention in bone. J Mat Sci Mat Med 1995; 6: 749-53.

[55] Ellingsen JE, Johansson CB, Wennerberg A, Holmen A. Improved retention and bone-to-implant contact with fluoride-modified titanium implants. Int J Oral Maxillofac Imp 2004; 19: 659-66.

[56] Gaggl A, Schultes G, Muller WD, Karcher H. Scanning electron microscopic analysis of laser-treated titanium implant surfaces: A comparative study. Biomaterials 2000; 21: 1067-73.

[57] Hallgren C, Reimers H, Chakarov D, Gold J, Wennerberg A. An in vivo tudy of bone response to implants topographically modified by laser micromachining. Biomaterials 2003; 24: 701-10.

[58] Frenkel SR, Simon J, Alexander H, Dennis M, Ricci JL. Osseointegration on metallic implant surfaces: Effects of microgeometry and growth factor treatment. J Biomed Mater Res 2002; 63: 70613.

[59] Jansen JA,Wolke JGC, Swann S, van der Waerden JPCM, de Groot $\mathrm{K}$. Application of magnetron-sputtering for producing ceramic coatings on implant materials. Clin Oral Implan Res 1993; 4: 2834.

[60] Kwak HB, Kim JY, Kim KJ, et al. Risedronate directly inhibits osteoclast differentiation and inflammatory bone loss. Biol Pharm Bull 2009; 32: 1193-8.

[61] Yoshinari M, Oda Y, Inoue T, Matsuzaka K, Shimono M. Bone response to calcium phosphate-coated and bisphosphonateimmobilized titanium implants. Biomaterials 2002; 23: 2879-85.

[62] Josse S, Faucheux C, Soueidan A, et al. Novel biomaterials for bisphosphonate delivery. Biomaterials 2005; 26: 2073-80.

[63] Meraw SJ, Reeve CM. Qualitative analysis of peripheral periimplant bone and influence of alendronate sodium on early bone regeneration. J Periodontol 1999; 70: 1228-33.
[64] Meraw SJ, Reeve CM, Wollan PC. Use of alendronate in periimplant defect regeneration. J Periodontol 1999; 70: 151-8.

[65] Kajiwara H, Yamaza T, Yoshinari M, et al. The bisphosphonate pamidronate on the surface of titanium stimulates bone formation around tibial implants in rats. Biomaterials 2005; 26: 581-7.

[66] Yoshinari M, Oda Y, Ueki H, Yokose S. Immobilization of bisphosphonates on surface modified titanium. Biomaterials 2001; 22: 709-15.

[67] Goldstein JL, Brown MS. Regulation of the mevalonate pathway. Nature 1990; 343: 425-30

[68] Mundy G, Garrett R, Harris S, et al. Stimulation of bone formation in vitro and in rodents by statins. Science 1999; 286: 1946-9.

[69] Ayukawa Y, Yasukawa E, Moriyama Y, et al. Local application of statin promotes bone repair through the suppression of osteoclasts and the enhancement of osteoblasts at bone-healing sites in rats. Oral Surg Oral Med Oral Pathol Oral Radiol Endod 2009; 107 (3): 336-42.

[70] Edwards CJ, Hart DJ, Spector TD. Oral statins and increased bonemineral density in postmenopausal women. Lancet 2000; 355 : 2218-9.

[71] Montagnani A, Gonnelli S, Cepollaro C, et al. Effect of Simvastatin treatment on bone mineral density and bone turnover in hypercholesterolemic postmenopausal women: A 1-year longitudinal study. Bone 2003; 32: 427-33.

[72] Yang F, Zhao SF, Zhang F, He FM, Yang GL. Simvastatin-loaded porous implant surfaces stimulate preosteoblasts differentiation: An in vitro study. Oral Surg Oral Med O Oral Surg Oral Med Oral Pathol Oral Radiol Endod 2010; 111(5): 551-6.

[73] Alt V, Bitschnau A, Osterling J, et al. The effects of combined Gentamycin-hydroxyapatite coating for cementless joint prostheses on the reduction of infection rates in a rabbit infection prophylaxis model. Biomaterials 2006; 27: 4627-34.

[74] Herr Y, Woo J, Kwon Y, Park J, Heo S, Chung J. Implant surface conditioning with Tetracycline-HCl: A SEM study. Key Eng Mat 2008; 361: 849-52

[75] Persson LG, Ericsson I, Berglundh T, Lindhe J. Osseointegration following treatment of peri-implantitis and replacement of implant components: An experimental study in the dog. J Clin Periodontol 2001; 28: 258-63.

[76] Avila G, Misch K, Galindo-Moreno P, Wang HL. Implant surface treatment using biomimetic agents. Implant Dent 2009; 18: 17-26.

[77] Becker J, Kirsch A, Schwarz F, et al. Bone apposition to titanium implants biocoated with recombinant human bone morphogenetic protein-2 (rhBMP-2): A pilot study in dogs. Clin Oral Invest 2006; 10: $217-24$

[78] Sigurdsson TJ, Nguyen S, Wikesjo UM. Alveolar ridge augmentation with rhBMP-2 and bone-to-implant contact in induced bone. Int J Periodont Rest 2001; 21: 461-73.

[79] Schouten C, Meijer GJ, van den Beucken JJ, Spauwen PH, Jansen JA. Effects of implant geometry, surface properties, and TGF- $\beta 1$ on peri-implant bone response: An experimental study in goats. Clin Oral Implan Res 2009; 20; 421-9.

[80] Researchers increase the success rate of tooth implants 2013. Available from:

http://www.alphagalileo.org/ViewItem.aspx?ItemId=130683\&Cult ureCode $=$ en

[81] Bougas K, Jimbo $\mathrm{R}$, Vandeweghe $\mathrm{S}$, et al. In vivo evaluation of a novel implant coating agent: Laminin-1. Clin Implant Dent Relat Res 2013; doi: 10.1111/cid.12037

\begin{tabular}{ll}
\hline Received: January 10, 2014 & Revised: January 27, 2014
\end{tabular}

Accepted: February 12, 2014

(C) Celeste M. Abraham; Licensee Bentham Open.

This is an open access article licensed under the terms of the Creative Commons Attribution Non-Commercial License (http://creativecommons.org/licenses/by-nc/3.0/) which permits unrestricted, non-commercial use, distribution and reproduction in any medium, provided the work is properly cited. 